\title{
Chinese Engagement Abroad in the Scrap Business
}

\section{Yvan Schulz}

\section{(2) OpenEdition}

\section{Journals}

\section{Electronic version}

URL: https://journals.openedition.org/chinaperspectives/11225

DOI: 10.4000/chinaperspectives. 11225

ISSN: 1996-4617

\section{Publisher}

Centre d'étude français sur la Chine contemporaine

\section{Printed version}

Date of publication: 1 December 2020

Number of pages: $49-57$

ISSN: 2070-3449

\section{Electronic reference}

Yvan Schulz, "Chinese Engagement Abroad in the Scrap Business", China Perspectives [Online],

2020/4 | 2020, Online since 01 December 2020, connection on 10 December 2021. URL: http:// journals.openedition.org/chinaperspectives/11225 ; DOI: https://doi.org/10.4000/chinaperspectives. 11225

(c) All rights reserved 


\title{
Chinese Engagement Abroad in the Scrap Business
}

YVAN SCHULZ

\begin{abstract}
This paper explores the changing nature of Chinese engagement abroad in the scrap business. Based on primary sources and interviews conducted by the author, it identifies the factors that, at different times, led Chinese scrap dealers and recyclers to extend the scope of their professional activity beyond the borders of their home country. Drawing on recent scholarship in discard studies, the author argues that it is necessary to move beyond the environmental dumping narrative in order to better understand Chinese national policy and its implications. This narrative serves as the main official justification for the bans on imports of recyclable waste that the central government adopted in recent years. However, there is good reason to believe that, by adopting a highly restrictive stance on the international waste trade, the central government sought first and foremost to bolster the municipal solid waste management sector within China. In turn, official support for domestic industrial players makes it possible for some Chinese corporations to emerge as providers of waste collection and recycling services at the international level. The trend, described in the paper, has already begun. It marks a shift from globalisation from below to globalisation from above.
\end{abstract}

KEYWORDS: Recyclable waste, environmental dumping, international trade, discard studies, global China.

\section{Introduction}

Since the late 2010s, discussions on the transnational trade in recyclable waste tend to centre on China. In particular, the announcement by the Chinese central government of a ban on imports of 24 categories of scrap in July 2017 drew considerable attention worldwide. It brought to the forefront the predominant role played by China in the contemporary commerce and conversion of discarded goods, a sector that has globalised in the late twentieth and early twenty-first centuries.

Chinese engagement in the global trade and transformation of recyclable waste is not new, even though it rarely made international headlines until recently. Yet, detailed and comprehensive accounts of the phenomenon are lacking (a notable exception is Minter 2013). In particular, there exists no systematic study of the presence of Chinese socioeconomic actors abroad. The present paper fills this gap. Using a historical perspective, it reveals what led Chinese scrap dealers and recyclers to extend the scope of their professional activity beyond the borders of their home country and describes the changing nature of their activities.

In terms of methods, the paper invokes findings that stem in part from ethnographic fieldwork I conducted in Guangdong Province between 2014 and 2018, in part from documentary research I carried out using a wide range of sources, including academic and non-academic publications, press articles, and legal or other official documents. My main focus is on two categories of goods, namely discarded plastics and discarded electrical and electronic equipment (DEEE or "e-waste," dianzi laji, dianzi feiqiwu 電子垃 圾, 電子廢棄物). The latter category includes used smartphones, defunct air conditioners, and obsolete washing machines, for instance, as well as parts or components thereof. Discarded plastics and DEEE can be referred to as "scrap," because they are recyclable, at least to some extent. Yet, they are often called "waste," "debris," or "trash." There is no ontological difference between one set of terms and the other. As the saying goes, one man's trash is another's treasure (see Reno 2009). Whether or not a given object or material still possesses some value depends on a lot of factors, including available technologies, social networks, economic calculations, and moral values (Gille 2007). This article deals mainly with scrap in an extended sense, i.e., solid waste that is imbued with the potential of transforming (again) into a resource, i.e., a source of (secondary) raw materials.

In terms of conceptual framework, the paper draws inspiration from recent social science research on waste (aka discard studies), in particular work that seeks to explain the transnational trade in waste and global recycling economies. Debates on this topic have thus far largely been framed by the environmental justice paradigm (see Mohai et al. 2009; Pellow 2010), which perceives the waste products of the rich consumer societies of the Global North as a form of neocolonialism, as they are dumped on the peoples and environments of the Global South. Under this paradigm, the environmental costs of the consumer societies of the Global North are seen as being externalised through the use of nature in the Global South as an uncosted sink. However, as economic geographers Nicky Gregson and Mike Crang point out (2015: 153), more recent research on global recycling has challenged such accounts. It shows that they obscure a complex global trade in secondary resources that are recovered for manufacturing purposes. Gregson and Crang acknowledge that "high profile instances of toxic waste dumping continue to grab media headlines," but contend that these are the exceptions rather than the rule. They explain that most waste is actually harvested in the Global North by networks of buyers and traders from the Global South, then shipped to the Global South, where it is processed and recycled into even more manufactured goods, many of which find their way back to the Global North (ibid., see also 161). 
In the mid-2010s, the global trade in recyclable waste had become a multimillion-dollar business - in which, it should be noted, China played a predominant role. As Gregson and Crang rightly observe, the environmental justice paradigm does not account fully for this phenomenon. A planetwide displacement of pollution does take place, but there is more at stake in the transnational exchange of discarded objects and materials on a global scale (lles 2004; Rivoli 2005; Alexander and Reno 2012). Not only that, but the environmental justice paradigm often leads to the assumption that waste flows from the Global North to the Global South. This is reflected, inter alia, in the geographical imaginary of the Basel Convention, a key law governing the international waste trade. However, material flows are more complex and multi-directional (Lepawsky and McNabb 2010; Furniss 2015; Lepawsky 2015b), which raises questions about the relevance of current legal instruments (Lepawsky 2015a).

Based on the knowledge described above, I argue that the Chinese central government's embrace of the environmental dumping narrative needs to be taken with a pinch of salt. Not only does it misrepresent the crucial role scrap imports have played in the country's development in the past, it also obfuscates current national-level issues that are arguably more important than pollution arising from imported waste (Liebman 2018). Key among these is the expansion and upgrading of the domestic municipal solid waste (MSW) management sector, which features close collaboration between local governments and large corporations. As we shall see, this collaboration has a bearing of the current nature of Chinese engagement abroad in the scrap business.

Each of the following three sections corresponds more or less to a period in time and focuses on the presence abroad of a particular type of socioeconomic actor. The first one (1980s to 2000s) addresses Chinese scrap buyers, the second one (2010-2018) Chinese scrap processors, and the third one (2018-2020) Chinese scrap service providers, equipment makers, and facility builders.

\section{Buying scrap abroad}

Citizens from mainland China have been going abroad to make a living from scrap since the early 1990s. Their motive was to source goods that could serve as raw materials once recycled, and to ship them back to their country. The first wave of Chinese people who settled or invested abroad to make a living from scrap consisted mainly of private, often selfmade entrepreneurs who ran micro-, small, or medium-sized enterprises (MSMEs). It can be considered part of a wider phenomenon that some refer to as "globalisation from below" (Mathews et al. 2012) as opposed to the movement of goods, people, and capital driven by the activity of governments, corporations, and financial institutions.

\section{Taiwanese set the ball rolling}

By going abroad, businesspeople from China largely followed a trend set by their counterparts from Taiwan a decade or two earlier. In his account of the globalisation of the scrap trade at the turn of the twentieth century, Adam Minter tells the stories of several Taiwanese men who ventured to the United States and other faraway countries in order to obtain recyclable materials. One of them, Joe, started criss-crossing the United States in 1971 to buy low-grade scrap, which rising labour costs and environmental crackdowns in that country were making unattractive to domestic recyclers. Within a decade, Joe was able to establish his own scrapyard back home. John Seabrook writes about another Taiwanese businessman, a man named
Yaw Bin (Tony) Huang, who started out buying aluminium and copper scrap from dealers in the United States and selling it in Taiwan. After 15 years, Tony moved back to Taiwan and founded a company called Sigma, which Seabrook describes as "the largest recycler of aluminium in China" in the mid-2000s. ${ }^{2}$

In the late 1980s and early 1990s, a combination of push and pull factors led many Taiwanese businesspeople like Joe and Tony to relocate their operations to China. Among these factors were rising labour costs in Taiwan, an increasingly intolerant public and official stance on burning and dumping associated with the scrap industry, and a ban on imports of "mixed metal scrap" into Taiwan (Terao 2005) - which prefigured measures taken more recently by the Chinese government. At the time, China did not have any environmental regulations related to the import of scrap metal and only very few customs officials able to assess a duty on scrap. On the whole, this made business easier, although it also posed some challenges. The companies set up by Taiwanese businesspeople in China grew rapidly, thanks mainly to the country's insatiable appetite for recyclables, especially metals.

\section{Mainland Chinese jump on the bandwagon}

Like the Taiwanese - and following their example, to some extent - many mainland Chinese soon started to move across the globe looking for scrap to ship back to their home country. Perhaps the most famous of all is Cheung Yan, who became known in China and beyond as one of the world's richest women in the mid-2000s. In an interview published by The New Yorker in 2009, Cheung recalls her modest beginning as an accountant in Northeast China and explains how she and her husband made a fortune thanks to the wastepaper trade. ${ }^{3}$ The couple founded a company called America Chung Nam that bought old corrugated containers in the United States and shipped them to China, where they were used in the production of containerboard. "By 2001, Cheung's company had reached an extraordinary milestone," writes the interviewer, Evan Osnos; "it had surpassed global giants such as DuPont and Procter \& Gamble to become the single largest exporter, by volume, of freight from the United States. In other words, nobody in America was shipping more of anything each year anywhere in the world." The business expanded further, and Cheung eventually came to run China's largest paper manufacturer in the late 2000s, Nine Dragons Paper (Jiulong Zhiye 㺵龍紙業).

America Chung Nam is a true business success story, so it cannot be considered to be representative of all scrap-related Chinese ventures abroad. However, the particular opportunities that Cheung and her husband identified and seized while living and working in the United States arose from more general circumstances, notably: (1) the huge volume of recyclables generated by North-American consumption and the relatively effective collection systems in that part of the world; (2) the migration of manufacturing to China, which created a strong Chinese demand for materials such as old corrugated containers; and (3) the cost of shipping cargo from North America to China, which was lowered considerably by the fact that container vessels linking the two regions could not head back empty. Other circumstances such as the advent of consumerism in China and the limited availability of resources within that country also played an important role. Finally, Joshua Goldstein also mentions "labour outsourcing,

1. Adam Minter, "How China Profits From Our Junk," The Atlantic, $1^{\text {st }}$ November 2013, https://www. theatlantic.com/china/archive/2013/11/how-china-profits-from-our-junk/281044/ [reproduced in Minter 2013] (accessed on 15 July 2020).

2. John Seabrook, "American Scrap: An Old-School Industry Globalizes," The New Yorker, 6 January 2008, https:/www.newyorker.com/magazine/2008/01/14/american-scrap (accessed on 15 July 2020)

3. Evan Osnos, "Wastepaper Queen: She's China's Horatio Alger Hero. Will Her Fortune Survive?," The New Yorker, 23 March 2009, https://www.newyorker.com/magazine/2009/03/30/wastepaperqueen (accessed on 15 July 2020) 
the lowering of trade barriers, breakthroughs in containerization and shipping, and a virtual pandemic of urbanization" (Goldstein 2012: 342).

In the global scrap trade, the relationship between China and North America was particularly emblematic, in large part because it involved huge volumes of materials (see Brooks et al. 2018). However, more or less the same type of relationship could be observed between China and other industrialised regions of the world, notably Western Europe (see Velis 2014 on waste plastics) and Northeast Asia (see Terazono et al. 2004; Meng and Yoshida 2012).

While doing fieldwork in China in the mid-2010s, I interviewed several Chinese scrap traders who had operations abroad or were spending a considerable amount of time traveling outside of China for business purposes. One of them was Dave Zhuang. ${ }^{4}$ I met him in Singapore in November 2014, during a guided tour of a recycling plant. Zhuang has built his career on the cross-border trade in scrap and dedicated his life to this professional activity. While we talked, he told me that it had always been his "dream" (mengxiang 夢想) to make a living from scrap trading, and that he had worked hard to make this dream come true. In the mid-2000s, Zhuang founded what eventually became one of China's main online platforms for finding information on prices and trading scrap. Later, Zhuang launched his own company, which sourced scrap from all over the world and supplied mainly China-based customers. The company exported goods, including DEEE, from foreign countries and sometimes imported them into China as well. On the latter point, Zhuang insisted that his company only imported authorised goods, which excluded DEEE. But he made no secret of the fact that his customers brought DEEE into China through "smuggling" (zousi 走 私). Zhuang's company was headquartered in Ningbo (Zhejiang Province) and had offices and scrapyards in many countries, including not only China but also Spain, Pakistan, and the United States. Zhuang spent only a third of his time in Ningbo. The other two thirds he spent in scrapyards abroad and in hotels, airplanes, or rental cars, respectively. He joked that his family never knew where he was.

In May 2015, while doing fieldwork in Qingyuan, I met with two brothers who specialised in copper-containing cables and "mixed metals" (zahuo 雜 貨). Hu Ge and Hu Di, as I shall call them here, bought goods abroad from some of the world's leading recycling companies (e.g., SIMS Recycling, One Steel), shipped them to Qingyuan, and processed them in their own scrapyards, using mostly manual labour and a few basic machines. The brothers travelled frequently to foreign countries and possessed multi-year business visas for several of them, including the United States, Australia, and the United Kingdom. Hu Ge, who was in his mid-fifties, had been involved in this line of business for 20 years. Having visited many places outside of China, he was not short of anecdotes about his business trips and parallel sightseeing activities. While we were chatting, he showed me pictures he had taken on the other side of the planet. Even though they did not speak English, the two brothers clearly had cosmopolitan leanings and considered themselves members of a large, global family of scrap traders.

\section{Developing countries become a destination}

Up until the turn of the century, Chinese individuals and companies that bought scrap abroad to ship back to China principally settled or invested in regions of the world such as North America and Western Europe. Starting in the 2000s, however, some of them also ventured into less industrially advanced and economically developed regions, including Africa, Southeast Asia, South Asia, and the Middle East. If we focus on DEEE and the mid2010s, for instance, Chinese businessmen could be found in a number of
African countries, including Ghana (Fernández-Font Pérez 2014), Kenya (Reboux 2017), and Nigeria (Sala, forthcoming). In these countries, they typically bought back printed circuit boards (PCBs) and wires or cables collected by self-employed workers and shipped them back home. What made this kind of economic activity viable is the fact that African countries had very few enterprises capable of extracting and refining valuables metals (e.g. gold, silver, copper) from these types of goods, whereas China had plenty, notably in large rural recycling hubs located along the coast (Tong and Wang 2012).

\section{Transforming scrap abroad}

In terms of protagonists, the second wave of Chinese engagement abroad in the scrap business features very much the same kind of socioeconomic actors as the first one, namely private, self-made entrepreneurs that ran family businesses or MSMEs. Therefore, like the first one, it can be described as globalisation from below.

Since the turn of the century, many of those specialising in DEEE and plastics decided to relocate their dismantling and/or processing operations outside of China. This is mainly due to China's national policy on scrap imports, which has changed considerably in a relatively short timeframe. Indeed, in just 20 years the policy went from being relatively permissive and weakly enforced to being extremely restrictive and strongly enforced. This section explores some of the effects of this rapid tightening up.

\section{DEEE is banned from import}

The first efforts to regulate scrap inflows to China date back to the mid$1990 s^{5}$ and were quickly applied to DEEE. The central government adopted an import ban on these types of goods in February $2000^{6}$ and expanded it in later years. ${ }^{7}$ At the end of the 2000s, a total of 55 categories of DEEE were prohibited from entering Chinese territory. However, the ban did not apply to all categories of DEEE; Chinese state authorities considered some of them useful and relatively unproblematic sources of raw materials, and therefore authorised them under certain conditions. ${ }^{8}$

There is good reason to believe that the main goal pursued through the import ban has changed over the years. Initially, it may have been to stick a spoke in the wheels of the reuse economy, a vibrant sector in reform-era China (Minter 2013), in order to help Chinese brands grow and gain more

4. Names have been anonymised.

5. Standing Committee of the National People's Congress, “中華人民共和國固體廢物污染環境 防治法" (Zhonghua renmin gongheguo guti feiwu wuran huanjing fangzhi fa, Law of the People's Republic of China on the Prevention and Control of Environmental Pollution by Solid Wastes), 1995 [revised in 2004, 2013 and 2016], http://en.pkulaw.cn/display.aspx?cgid=826df5acc275f7d 7 bdfb\&lib=law (accessed on 15 July 2020).

6. State Environmental Protection Administration, “關于進口第七類廢物有關問題的通知” (Guanyu jinkou diqi lei feiwu youguan wenti de tongzhi, Notification on Import of the Seventh Category of Wastes), 2000, http://www.law-lib.com/LAW/law_view.asp?id=108786 (accessed on 15 July 2020).

7. Ministry of Foreign Trade and Economic Cooperation et al. “禁止進口貨物目錄” (Jinzhi jinkou huowu mulu, List of Goods Prohibited From Import), 2002, http://www.mee.gov.cn/gkml/hbb/ gwy/200910/t20091030_180691.htm (accessed on 29 September 2019); SEPA, “禁止進口固 體廢物目錄” (Jinzhi jinkou guti feiwu mulu, Catalog of Solid Waste Prohibited From Import), 2008, http://www.mep.gov.cn/gkml/zj/gg/200910/t20091021_171792.htm (accessed on 15 July 2020); Ministry of Environmental Protection, “關于調整進口廢物管理目錄的公告” (Guanyu tiaozheng jinkou feiwu guanli mulu de gonggao, Announcement on the Adjustment of the Catalog on the Management of Imported Waste), 2009, http://www.mee.gov.cn/gkml/hbb/bgg/200910/ t20091022_174566.htm (accessed on 15 July 2020).

8. See "進口七類廢物標準” (Jinkou qilei feiwu biaozhun, Standards for the Imports of Wastes from the Seventh Category), Mymetal.net, 6 July 2016, http://www.mymetal. net/16/0706/11/87FC754217FADD3A.html (accessed on 15 July 2020). 
market share. ${ }^{9}$ Later on, after a scandal erupted in connection with severe pollution in Guiyu, a town located in the eastern part of Guangdong Province, the central government mainly sought to put an end to the pollution caused by DEEE dismantling and processing workshops. ${ }^{10}$ Since then, environmental protection acts as the main official justification - although protectionism arguably has not lost its validity as an explanatory factor.

Despite the regulatory efforts described above, flows of DEEE into China continued more or less unabated until the early 2010s, as my interviews indicate (see also Grossman 2007: 199). This was mainly due to lack of implementation and weak enforcement (Ni and Zeng 2009: 3993; Chung and Zhang 2011: 2639; Wang et al. 2013: 31). In addition, imports were tolerated in some cases, though not officially. For instance, Chinese state authorities turned a blind eye to the trade in scrap PCBs and second-hand DEEE intended for re-export that took place between Vietnam and China during the mid-2000s (Yoshida 2005; Shinkuma and Huong 2009: 27). Finally, loopholes also made it possible for DEEE to find its way into China. For instance, shipments of mixed metal scrap for recycling that contained a small proportion of DEEE were still deemed compliant.

\section{Crackdown operations close the valves}

In the early 2010s, the central and provincial governments took action to better control and monitor imports of scrap and waste material. In August 2011, five ministries jointly issued new administrative measures ${ }^{11}$ with the aim of tackling practices that had become common in China's recycling sector despite being unlawful, including the borrowing, renting, or selling of import licenses, the reselling of imported waste, and the importing of waste that does not qualify as raw materials. This legal text made clear that violations would be punished and specified the penalties. By doing so, it set the tone for what was to follow.

Starting in 2013, the Ministry of Environmental Protection, the General Administration of Customs, and the General Administration of Quality Supervision, Inspection, and Quarantine embarked on several nationwide "special joint operations" (lianhe zhuanxiang xingdong 聯合專項行動), which were aimed at monitoring scrap imports more closely and increasing the frequency, scale, and effectiveness of official inspections, notably in ports. These operations were dubbed "Green Fence" (Lüli 綠籬) $)^{12}$ and "National Sword" (Guomen lijian 國門利劍). ${ }^{13}$ They raised the bar very high in terms of quality and cracked down on smuggling and other illegal activities, thereby making China's borders more scraptight, so to speak.

In the mid-2010s, there were still indications of DEEE smuggling. ${ }^{14}$ For instance, I noted in February 2016 that a WeChat public account called "source of electronic goods" (dianzi huoyuan 電子貨源) offered mainland Chinese buyers quite openly a wide variety of electronic devices, parts, and components sourced abroad. Most goods were in new or used condition, but some were described as "rubbish" (laji 垃圾). The company behind the account also provided services to facilitate shipment to China. However, National Sword kicked in soon thereafter and may well have all but eradicated DEEE smuggling. Toward the end of my stay in China, the topic had become very sensitive and I had a hard time getting traders or recyclers to speak about it.

In line with crackdown operations, the official terminology on scrap imports changed dramatically. These types of objects became routinely referred to as "foreign rubbish" (yang laji 洋垃圾), decried as dirty and dangerous and depicted as a threat to the country. The authorities portrayed themselves as defenders acting to protect the Chinese people and their environment. This official stance, which marks the Chinese Party-state's embrace of the environmental dumping narrative, is worlds away from that of the 2000s. In order to understand the shift from one to the other, one needs to keep in mind the Chinese Communist Party's (CCP) broader adoption of the discourse of environmentalism in the 2010s. Faced with severe and ever-worsening environmental degradation, the CCP sought to not only attenuate it but also control the anxiety and discontent it caused among Chinese citizens, which represented a threat to political legitimacy. In order to depoliticise the issue, the powers that be came up with a form of environmentalism that had strong nationalist and techno-utopian dimensions. They encapsulated it in the watchword "ecological civilisation" (shengtai wenming 生態文明) and promoted it through a heavy use of green propaganda (Hubbert 2015; Goron 2018). The rhetoric of yang laji, which passes the buck for China's environmental woes to foreign powers and creates the impression that Chinese leadership is part of the solution rather than the problem, illustrates this well: it is built around the arguments of self-defence, pollution prevention, and national pride (see Liebman 2018).

Chinese national policy on imports became even more restrictive in July 2017 when the central government imposed a total ban on no less than 24 categories of scrap, including unsorted waste paper, tires, textiles, glass, and the vast majority of postconsumer plastics. ${ }^{15}$ By prohibiting postconsumer plastics, the ban added a further restriction on imports of DEEE, because, at the time, plastics found in DEEE were still being collected abroad and sent to China in large quantities. This wide-ranging ban came as a shock and quickly made headlines worldwide. ${ }^{16}$ It signalled a drastic change: China would no longer serve as the world's outlet for waste material - or the world's "dump," to use a term encountered more frequently in media reports. As a result, vast quantities of recyclable waste would be displaced to other countries - for plastic waste, one estimate puts the figure at 111 million metric tons by 2030 (Brooks et al. 2018: 2). By the time the ban had come into effect in January 2018, even non-specialists were aware that the Chinese Partystate had fundamentally transformed the global scrap trade. And Beijing did not stop there. As of mid-2019, another eight categories of scrap have been banned from import, including key industrial metals, and 16 other categories are awaiting the same fate. ${ }^{17}$ Based on these developments, observers predict that very little scrap or waste material will flow into China in the future. ${ }^{18}$

9. Robin Ingenthron, "Why We Should Ship Our Electronic 'Waste' to China and Africa," Motherboard, 31 March 2011, https://motherboard.vice.com/en_us/article/d77w9m/e-waste-recycling-exportsare-good (accessed on 15 July 2020).

10. See Jim Puckett et al.,"Exporting Harm: The High-Tech Trashing of Asia," Basel Action Network and Silicon Valley Toxics Coalition, 25 February 2002, http://www.ban.org/E-waste/ technotrashfinalcomp.pdf (accessed on 15 July 2020).

11. Ministry of Environmental Protection et al., "固體廢物進口管理辦法” (Guti feiwu jinkou guanli banfa, Administrative Measures for the Import of Solid Waste), 2011, http://www.lawinfochina. com/display.aspx?lib=law\&id=8862\&CGid=\#menu1 (accessed on 15 July 2020).

12. See, e.g., Patty Moore and Sally Houghton, "An Inside Look at Operation Green Fence," Resource Recycling, 18 October 2013, https://resource-recycling.com/recycling/2013/10/18/inside-lookoperation-green-fence/ (accessed on 15 July 2020).

13. See General Administration of Customs, “全國海關部署“國門利劍2016'打私行動” (Quanguo haiguan bushu "guomen lijian 2016" dasi xingdong), [no date], http://www.gov.cn/ xinwen/2016-03/11/content_5052289.htm (accessed on 15 July 2020).

14. See, e.g., "Police Bust 'E-trash' Smugglers, Seize 72,000 Tons of Goods," Global Times, 26 February 2014, http://www.globaltimes.cn/content/844788.shtml (accessed on 15 July 2020).

15. State Council, “禁止洋垃圾入境推進固體廢物進口管理制度改革實施方案” (Jinzhi yang laji rujing tuijin guti feiwu jinkou guanli zhidu gaige shishi fang'an, Implementation Plan for Prohibiting the Entry of Foreign Garbage and Advancing the Reform of the Solid Waste Import Administration System), 18 July 2017, http://www.gov.cn/zhengce/content/2017-07/27/ content_5213738.htm (accessed on 15 July 2020).

16. See, e.g., "A Chinese Ban on Rubbish Imports is Shaking up the Global Junk Trade," The Economist, 27 September 2018, https://www.economist.com/special-report/2018/09/27/a-chinese-ban-onrubbish-imports-is-shaking-up-the-global-junk-trade (accessed on 15 July 2020).

17. "Additional Scrap Grades Now on China's Restricted List," Recycling Today, 8 January 2019, https://www.recyclingtodayglobal.com/article/china-adds-scrap-metal-restricted-list-2019/ (accessed on 15 July 2020).

18. Colin Staub, "China Reiterates Total Ban and Tries to Define 'Solid Waste'," Resource Recycling, 9 April 2019, https://resource-recycling.com/recycling/2019/04/09/china-reiterates-total-banand-tries-to-define-solid-waste/ (accessed on 15 July 2020). 


\section{China's rural recycling economy collapses}

In parallel with the progressive tightening up of Chinese national policy on imports of recyclable waste from the early 2010s onwards, the official stance towards rural recycling hubs also changed dramatically. These towns and villages located in the countryside and specialised in the sorting, dismantling, and processing of various types of scrap had played a key role in reform-era industrial networks in China, yet they started to face growing pressure from state authorities at the district level and above.

Going back to the conversation I had with the Hu brothers in Qingyuan in 2015, what struck me is how concerned they were about the image of them and their profession that I would convey in what they called my "report" (baodao 報道). Very quickly, they told me that they had agreed to share information about their business activities because they hoped that I would emphasise positive things, not negative ones - in particular not pollution. What mattered most, they argued, was that measures had already been taken to upgrade the recycling sector in Qingyuan and attenuate its environmental impact. Hu Ge and Hu Di sought to distinguish themselves from other recyclers based in the same region, who engaged in more or less the same activities, only on a smaller scale. They stressed that their scrapyard, where I had bumped into them, was located inside a well-established industrial park run by a state-owned company that reports directly to the central government and possesses all necessary authorisations. According to them, this made their operations fundamentally superior to those located outside the park, in the surrounding countryside. To buttress their claim, they stressed that the industrial park was equipped with a water treatment facility.

In order to understand the brothers' statements, we need to place them in the context of the far-reaching transformation of the Chinese recycling sector that took place in the mid-2010s (see Schulz 2018). At the time, local governments in several rural recycling hubs throughout China conducted crackdowns with the aim of shutting down the vast majority of small recycling workshops (Goldstein 2017; Lora-Wainwright 2017; Schulz 2019; Schulz and Lora-Wainwright 2019). The enterprise run by the Hu brothers was well-positioned and relatively successful, but also middle-sized (they employed roughly 50 workers) and therefore potentially vulnerable to such drastic state measures. By describing their operations as "formal" (zhenggui 正規), "legal" (hefa 合法), and "clean" (qingjie 清潔), Hu Ce and Hu Di sought to place themselves on the right side of history. They understood that, as private entrepreneurs involved in the scrap trade, they had to side with the authorities, or at least embrace official discourse, or else their days would be numbered.

And yet, the Hu brothers' efforts may have been in vain. In January 2017, I realised by visiting Hu Ge's social media account that he had started a new business and was selling decorative ceramic articles in large quantities. This suggests that he may have had to abandon the scrap trade, which is something many of his peers have done (see Schulz and Lora-Wainwright 2019).

\section{Scrap processing moves abroad}

Together, the new Chinese national policy on imports of recyclable waste and the intense official pressure on workshops and small companies involved in recycling in the Chinese countryside triggered both a redirection of global flows ${ }^{19}$ (Brooks et al. 2018) and a redistribution of global dismantling, sorting, and processing activities.

Scrap exporters based abroad who used to rely on shipments to China could not do so anymore, and many of them turned to other outlets. The high availability of scrap on the global market pushed certain countries to take on a more prominent role as importers. Imports of waste plastics to
Thailand, Malaysia, and Vietnam, in particular, grew dramatically, thanks in large part to the fact that these countries had fewer import regulations and less stringent controls, or none at all. For a few years, at least, Southeast Asia absorbed a significant part of the volume of waste plastics that had once entered China. ${ }^{20}$ At the same time, sorting and processing capacity increased in this region. Places such as Minh Khai, a village in North Vietnam that specialises in waste plastics, experienced a recycling boom that generated not only more prosperity but also more pollution locally (Le Meur 2019: 336).

Likewise, China-based scrap processors who used to rely on imports of foreign goods could not do so anymore, and some of them relocated their activities abroad. The trend may have started earlier among recyclers specialising in DEEE than among those specialising in plastics or other materials, since DEEE was banned from entering China comparatively early. While doing research in Guangdong Province, I heard many stories of local inhabitants who had moved abroad, especially to Southeast Asia, and set up recycling operations there. According to one media account of the situation in Thailand, "Chinese businessmen have set about attempting to open about 100 plastic and e-waste recycling plants" since January 2018. ${ }^{21}$

This topic emerged repeatedly from interviews I conducted in Guiyu in April 2018. Everyone I spoke with in that town and neighbouring ones seemed to know personally someone who was now living in a Southeast Asian country and making a living from recycling. For instance, Yang Liu, a young trader of waste plastics living just outside Guiyu, told me that several of his plastic recycler friends had moved abroad, including one to Vietnam and one to Malaysia. The latter had tried to convince Liu to join his venture, but failed. The initial plan involved four partners who would each invest ten million renminbi. This high figure surprised me, so Liu explained: "Some five million have to be spent on equipment alone. Once this is done, there are still a lot of other costs to cover." My reaction was to ask: "If it's so costly, then what's the point?", to which Liu replied:

Plastics recycling is good business. You can earn good money. Regardless of how much you invest, you can be sure that you'll start making profit after four or five months. That's why a lot of people here [i.e. in Guiyu and neighbouring towns] got involved in plastics recycling in the first place.

Profits were potentially considerable, but a lot of people who used to be involved in the recycling business in and around Guiyu had been forced to give up this economic activity in recent years, due to the progressive tightening up of China's scrap import policy and the crackdowns that affected recycling workshops and small plants (Schulz 2019). According to Liu, some people had switched to other lines of business, including e-commerce (see also Schulz and Lora-Wainwright 2019), while others had moved abroad.

Liu pointed out that even relative newcomers had invested in plastics recycling abroad. His younger sister and her husband, for instance, had recently set up a plastics processing plant in Thailand, even though they

19. Leslie Hook and John Reed, "Why the World's Recycling System Stopped Working," Financial Times, 25 October 2018, https://www.ft.com/content/360e2524-d71a-11e8-a85433d6f82e62f8 (accessed on 15 July 2020).

20. Ibid.

21. Hannah Ellis-Petersen, "Deluge of Electronic Waste Turning Thailand into 'World's Rubbish Dump'," The Guardian, 28 June 2018, https://www.theguardian.com/world/2018/jun/28/delugeof-electronic-waste-turning-thailand-into-worlds-rubbish-dump (accessed on 15 July 2020). 
possessed few skills and little expertise in that field. Like Liu's friend, the brother-in-law in question had also tried to convince him to join their venture, but to no avail. One of the reasons why Liu did not want to team up with the couple is that he thought ventures in countries such as Thailand, Vietnam, and Malaysia had poor prospects:

This type of investment is too risky. These countries are tourism hotspots, so you can be sure that the governments there will also launch environmental inspections soon.

Liu knew first-hand about the environmental impact of plastics recycling. In the past, he and his family had done some "processing" (jiagong 加工) using a "shredder" (fensuiji 粉碎機), a very noisy machine that consumes large amounts of electricity, and an "extruding pelletizer" (jiya zaoli $j i$ 擠壓 造粒機), which produces toxic fumes. When this type of activity became too risky due to the heightened frequency of "environmental inspections" (cha huanbao 查環保) in and around Guiyu, they gave up and focused exclusively on "commerce" (maimai 買賣).

Another one of my interviewees, who traded waste plastics like Liu, also thought that Chinese recyclers would soon become unwelcome in Southeast Asian countries due to their negative environmental impact:

Too many of our people have moved there and opened [recycling] plants. If that continues, the governments of these countries will realise that these plants cause pollution and they will start to control them more strictly.

As it happens, the official stance toward Chinese recyclers and the recycling boom more generally in Southeast Asia had already changed by the time I last visited Guiyu (in April 2018). In one emblematic case, which received media attention worldwide, ${ }^{22}$ the Thai customs and police forces raided a large dismantling and processing facility located just outside Bangkok, which belonged to a Chinese national and specialised in DEEE (including plastics contained in DEEE). Photographs of the plant and its outside storage area show thousands of bulk bags filled to the brim and piled on top of each other, which suggests that the plant operated on a large scale, even though it did not qualify as "formal." Soon thereafter, the Thai government announced that it would stem the tide of recyclables flowing into Thailand by imposing an import ban, thereby following in the footsteps of the Chinese government. More or less at the same time, the governments of several other Southeast Asian countries, including Malaysia, Vietnam, and Indonesia, joined the movement by announcing import bans of their own. ${ }^{23}$ India has taken the same path, ${ }^{24}$ possibly setting an example for other South Asian countries to follow.

As a result, investing in Asia is not a really an option anymore for Chinese recycling companies seeking to relocate outside of China. The larger and more established companies, which can invest in infrastructure but will only do so in a predictable business environment, are considering other regions, e.g. Latin America and the Caribbean. ${ }^{25}$ For them, a key factor is proximity to the abundant source of recyclables that North America represents. Some companies are also assessing the feasibility of setting up recycling plants in the United States themselves. ${ }^{26}$ As for the smaller business entities, they seem to attach more importance to proximity with the destination market which China remains to a large extent - since most of them have chosen to settle in Southeast Asia.

Part of China's waste plastics processing capacity may have moved to
Southeast Asia, but the main market for recycled plastics from that region remains China itself. Wang Lei and his wife, who buy and sell "low grade" (diduan 低端) waste plastics and sort them manually close to Guiyu, explained to me in April 2018 that pellets produced through recycling could still be imported into China, because they did not count as waste, unlike unsorted and unprocessed plastic scrap. They stressed that when processing is done abroad, it causes no pollution within China. Therefore, according to them, it is unlikely that the Chinese government would ban imports of this type of material.

It is important to note that the relocation of some of China's processing capacity to developing countries did not start with the ban announced in July 2017, although it certainly gained speed from that moment on. To some extent, the phenomenon can be traced back further. In Africa, in particular, the presence of a significant number of Chinese processors specialising in waste plastics is attested in several countries since the late 2000s and early 2010s (see Furniss 2015 on Egypt; Xia 2019 on Tanzania; and Bräutigam et al. 2018 on Tanzania, Chana, Ethiopia and Nigeria). Key factors that pushed these Chinese processors to move away from home at the time include high competition among recycling enterprises and rising labour costs. Key factors that attracted them to Africa include a growing availability of recyclable waste and cheap labour costs.

\section{Offering scrap solutions abroad}

As we have seen above, in the span of only a few years, China has gone from being the world's main importer of recyclables to being a country whose borders are virtually impermeable to these types of goods. All the same, the country continues to be faced with massive quantities of waste. In 2017, the Chinese economy ranked second in the world in terms of nominal GDP and was growing much faster than that of all the economies in the top ten, with the exception of India's. Fast-paced industrialisation, widespread urbanisation, and the advent of consumerism, which have been going on in China for decades, have led to the generation of huge amounts of waste within the country (Goldstein 2012: 342) ${ }^{27}$ - and there promises to be even more in coming years, given the prospect of sustained economic growth.

This profusion of waste must be dealt with, in one way or another. The current leadership acknowledges the problem and has started to tackle it head-on. Over the past few years, one of its main ambitions has consisted in upgrading domestic waste management. This is particularly evident in MSW collection in urban areas, which has become a nationwide priority significantly, Chinese President Xi Jinping himself champions the cause. ${ }^{28}$ From 2017 to 2019, the State Council and national-level agencies adopted

22. E.g.ibid.

23. Colin Staub, "Import Restrictions Ripple Across Southeast Asia," Resource Recycling, 5 June 2018, https://resource-recycling.com/recycling/2018/06/05/import-restrictions-ripple-acrosssoutheast-asia/ (accessed on 15 July 2020).

24. Harry Cockburn, "India Bans Imports of Waste Plastic to Tackle Environmental Crisis," The Independent, 7 March 2019, https://www.independent.co.uk/environment/india-plastic-wasteban-recycling-uk-china-a8811696.html (accessed on 15 July 2020).

25. Steve Toloken, "China's Recyclers Look at Latin America, Caribbean," Plastic News, 3 April 2019, https://www.plasticsnews.com/article/20190403/NEWS/190409967/china-s-recyclers-look-atlatin-america-caribbean (accessed on 15 July 2020).

26. Lindsey Jacobson, "Why Chinese Companies are Investing in American Recycling," CNBC, $1^{\text {st }}$ March 2020, https://www.cnbc.com/2020/02/28/why-chinese-companies-are-investing-inamerican-recycling.html (accessed on 15 July 2020).

27. World Bank, "Waste Management in China: Issues and Recommendations," Urban Deveopment Working Papers, nr. 9, May 2005, https://siteresources.worldbank.org/INTEAPREGTOPURBDEV/ Resources/China-Waste-Management1.pdf (accessed on 15 July 2020).

28. "Xi Jinping Stresses Habit of Garbage Sorting," CGTN, 3 June 2019, https://news.cgtn.com/news/ 3d3d774d3459444d35457a6333566d54/index.html (accessed on 15 July 2020). 
a series of measures ${ }^{29}$ aimed at bringing into being state-controlled systems for MSW sorting in all large Chinese cities, once and for all. On paper at least, such systems had been in place since the 2000s, but they remained all but ineffective (see, e.g., Zhang 2015 on Guangzhou and Tong and Tao 2016 on Beijing). Scrap-related activities in large cities were dominated by market mechanisms and internal migrants belonging to the so-called "informal sector" (fei zhenggui jun 非正規軍, i.e., self-employed workers, family businesses, and MSMEs; see Zhang 2019), which stood in the way of government plans to "formalise" (zhengguihua 正規化). City governments throughout China had been grappling with the issue for more than a decade when the central government stepped in, imposing a target recycling rate of $35 \%$ by 2020 , among other things. Suddenly, they needed to seriously ramp up their efforts. The municipality of Shanghai, for instance, made MSW sorting compulsory, first for sanitation workers ${ }^{30}$ and later for city residents. ${ }^{31}$

The central government's restrictive stance on scrap imports needs to be interpreted in light of the above. There is good reason to believe that the goals of strengthening China's domestic waste collection and recycling industry and increasing its resource autonomy weighed more heavily in official considerations than that of preventing environmental dumping, be it only because, by the time the 2017 import ban was announced, foreign scrap was actually "immaculate," according to Minter. ${ }^{32}$ The rationale behind the banning of imports may have been to create scarcity, push domestic prices upwards, and make it easier (because more profitable) to capture recyclables. It was definitely part of a larger plan to move the Chinese recycling industry from artisanal to industrial and prop up state-run systems.

The central government's ambition to radically transform China's domestic waste industry can be seen not only in its efforts to increase collection rates, but also in its programme to upgrade the management and treatment of various types of recyclable wastes, in particular DEEE. In the early 2010s the powers that be entrusted DEEE dismantling and shredding to companies that own vast facilities, use state-of-the-art technology, and are able to handle complex bureaucratic procedures. By favouring large socioeconomic entities, including through subsidies, they aimed to squeeze out small ones, in particular "informal" recyclers, deemed problematic on account of their size (too "small," xiao 小), spatial distribution (too "scattered," san 散), operational mode (too "disorderly," luan 亂), and environmental impact (too polluting or "dirty," zang 骿) (Schulz 2015). Success on this front took time - indeed, it has not yet been fully reached ten years down the line - but what officials in Beijing managed to achieve quickly was to bring into being a new subsector composed of more than a hundred large companies specialized in DEEE recycling (Schulz 2018). Many of these companies belong to large Chinese groups specialising in electronics, e.g., TCL Technology, one of the world's largest manufacturer of television sets. And only a handful are attached to foreign groups.

Large companies specialising in scrap recycling are currently growing rapidly in China thanks to the unique opportunity created by official policy, state support, and widely available public money. As a result, some have decided to branch out overseas. Shenzhen-listed GEM Co. Ltd. is a good example. The company, which specialises in DEEE recycling and develops related technology and equipment, recently invested in the construction of industrial parks in South Africa, Indonesia, and South Korea. According to its website, ${ }^{33}$ GEM strives to "become a world-leading green enterprise" by "actively participat[ing] in global waste recycling industry cooperation." Explicit reference is made to the central government's global development strategy: "CEM will (...) build the green industry to connect with the 'Belt and Road' Initiative." And GEM sees as its mission to implement the "green development concept of the
Chinese government" and "show the world [the] responsibility of Chinese environmental protection companies." In other words, the company portrays itself as an ambassador for official plans to promote China as an upcoming leader in sustainable solutions to the global environmental predicament.

Many of the large waste management companies that are expanding abroad are state-owned. These companies' core business is waste treatment and disposal - Capital Environment Holdings Limited (CEHL) and Everbright International, for instance, are both known as major players in China's incineration ("waste-to-energy") business - but they generally also have departments or subsidiaries specialising in scrap collection, sorting, and processing. They invest, provide a wide range of waste-related solutions and services, and build facilities abroad, including in Belt and Road Initiative (BRI) member countries. By doing so, they are emerging as international players and starting to compete in the global arena with more established, non-Chinese companies, e.g., Waste Management Inc. and Veolia Environmental Services.

In sum, we are now witnessing a third wave of Chinese engagement abroad in the scrap business. Unlike the previous two, this one features large corporations, most of which have strong links with Chinese state authorities. It results chiefly from the growth and modernisation of China's domestic waste management industry in recent years and the official strategy to push Chinese corporations to invest and develop activities in foreign countries, be it in the name of the BRI or the older "going-out" (zouchuqu 走出去) policy.

\section{Conclusion}

This paper provided an historical account of Chinese engagement in the trade and transformation of recyclable waste abroad as well as a description of current trends. Focusing on discarded plastics and discarded electrical and electronic equipment (DEEE), it identified three waves (or phases) and described their respective characteristics. As we have seen, the scope, forms, and modalities of Chinese engagement abroad in the scrap business have varied according to the area and era under consideration.

For many years, Chinese socioeconomic entities operating abroad engaged exclusively in trade. It is only after 2010 that some of them also began to sort, dismantle, and process waste in foreign countries. Likewise, the story about this form of Chinese engagement abroad has long been mainly about self-employed workers, family businesses, and MSMEs, as those were the actors that derived their livelihood or profit from the trade, transportation, and transformation of scrap, especially with regard to discarded plastics and DEEE. My account of these two first waves highlighted the calculations made, the risks taken and the obstacles faced by the actors involved in connection with their presence overseas, thereby drawing a (partial) portrait of the Chinese petty capitalist economy as it engaged abroad in the late twentieth and early twenty-first century.

29. For a list, see Chang Jiwen, “推進垃圾分類要保持歷史耐心” (Tuijin laji fenlei yao baochi lishi naixin, The push for garbage sorting requires historical patience), Kexue wang, 18 June 2019, http://news.sciencenet.cn/htmlnews/2019/6/427512.shtm (accessed on 15 July 2020).

30. Teng Jingxuan and Ge Mingning, "Shanghai Talks Trash," Caixin Clobal, 18 May 2018, https://www. caixinglobal.com/2018-05-18/shanghai-talks-trash-101252423.html (accessed on 15 July 2020).

31. Wu Yixiu, "Shanghai's Compulsory Waste Sorting Begins," China Dialogue, 2 July 2019, https:// chinadialogue.net/en/cities/11349-shanghai-s-compulsory-waste-sorting-begins/ (accessed on 15 July 2020).

32. Charlotte Middlehurst, "Q\&A [with Adam Minter]: China's waste ban debate is 'misinformed' and 'one-dimensional'," China Dialogue, August 24, 2018, https://chinadialogue.net/en/ pollution/10789-q-a-china-s-waste-ban-debate-is-misinformed-and-one-dimensional/ (accessed on 15 July 2020).

33. CEM, "Company Profile," [no date], http://en.gem.com.cn/index.php/gongsijianjie/ (accessed on 15 July 2020). 
Today, a new form of Chinese engagement abroad is in the making. As far as one can judge from developments that date back only a few years, it features large corporations rather than grassroots entrepreneurs. All of these corporations benefit considerably from their direct collaboration with national, provincial, and municipal governments in China, which provide support, investment, and subsidies - not to speak of the occasional preferential treatment obtained through corruption. Many of these corporations are even owned by the Chinese state - which, in a way, is reminiscent of the waste management system set up by the Party-state in China in Maoist times (see Goldstein 2005). Without state backing, it is unlikely that these corporations would have been able to venture abroad.

In sum, whereas the two first waves of Chinese engagement abroad in the scrap business qualify as "globalisation from below," the third one fits with classic understanding of globalisation as a phenomenon driven mainly by the world's governments, corporations, and major financial institutions, in other words as something "from above." The third wave also marks a transition away from a scrap collection and recycling sector populated chiefly by private, independent actors towards one where public actors play a predominant role. This evolution reflects the firm grip that China's current leadership has taken on the economy.

By moving the cursor back and forth between scales, this paper has revealed the links that exist between China's national and international policies. It has shown, in particular, that the yang laji rhetoric should not be taken at face value, but rather understood as part of a wider effort by the central government to upgrade domestic recycling and place it back within the purview of the state. Establishing formal recycling systems is a big challenge, not only for China, but for all "emerging" economies, and even more so for developing countries, which have the world's fastest-growing waste generation rates. And behind every challenge lies an opportunity. For the Chinese authorities and the corporations they collaborate with, the opportunity consists of taking full advantage of the experience they have gained and are still gaining at home to export their expertise and solutions abroad. That they have identified and are seizing this opportunity is evident in the discourse on sustainability that accompanies the promotion of the BRI as well as in the emergence of quite a few Chinese corporations as major international players, despite fierce competition.

I Yvan Schulz holds a PhD in anthropology from the University of Neuchâtel. He is currently a lecturer at the University of Fribourg. Yvan Schulz, Marronniers 19, 1800 Vevey, Switzerland (yvan.schulz@yahoo. com)

Manuscript received on 12 December 2019. Accepted on 14 September 2020.

\section{References}

ALEXANDER, Catherine, and Joshua RENO. 2012. "Introduction." In Catherine Alexander and Joshua Reno (eds.), Economies of Recycling: The Global Transformations of Materials, Values and Social Relations. London: Zed Books. 1-32.

BRÄUTIGAM, Deborah, Xiaoyang TANG, and Ying XIA. 2018. "What Kinds of Chinese 'Ceese' Are Flying to Africa? Evidence from Chinese Manufacturing Firms." Journal of African Economies 27(AERC Supplement 1): 29-51.

BROOKS, Amy L., Shunli WANG, and Jenna R. JAMBECK. 2018. "The Chinese Import Ban and Its Impact on Global Plastic Waste Trade." Science Advances 4(6).

CHUNG, Shan-Shan, and Chan ZHANG. 2011. "An Evaluation of Legislative Measures on Electrical and Electronic Waste in the People's Republic of China." Waste Management 31(12): 2638-46.

FERNANDEZ-FONT PEREZ, Rafael. 2014. "Tools for Informal E-Waste Recyclers in Agbogbloshie, Ghana." Master Thesis. London: Royal Holloway University of London.

FURNISS, Jamie. 2015. "Alternative Framings of Transnational Waste Flows: Reflections Based on the Egypt-China PET Plastic Trade." Area 47(1): 24-30.

GILLE, Zsuzsa. 2007. From the Cult of Waste to the Trash Heap of History: The Politics of Waste in Socialist and Postsocialist Hungary. Bloomington: Indiana University Press.

GOLDSTEIN, Joshua. 2012. "Waste." In Frank Trentmann (ed.), The Oxford Handbook of the History of Consumption. Oxford: Oxford University Press. 326-47.
GOLDSTEIN, Joshua. 2006. "The Remains of the Everyday: One Hundred Years of Recycling in Beijing." In Madeleine Yue Dong and Joshua Goldstein (eds.), Everyday Modernity in China. Seattle: University of Washington Press. 260-302.

GOLDSTEIN, Joshua. 2017. "A Pyrrhic Victory? The Limits to the Successful Crackdown on Informal Sector Plastics Recycling in Wenan County, China." Modern China 43(1): 3-35.

GORON, Coraline. 2018. "Ecological Civilisation and the Political Limits of a Chinese Concept of Sustainability." China Perspectives 115(4): 39-52.

GREGSON, Nicky, and Mike CRANG. 2015. "From Waste to Resource: The Trade in Wastes and Global Recycling Economies." Annual Review of Environment and Resources 40(1): 151-76.

GROSSMAN, Elizabeth. 2007. High Tech Trash: Digital Devices, Hidden Toxics, and Human Health. Washington: Island Press, Shearwater Books.

HOSODA, Eiji, and Takamasa HAYASHI. 2010. "A Cross-Border Recycling System in Asia under the Resource and Environmental Constraints: A Challenging Project by the City of Kitakyushu and the City of Tianjin." Sustainability Science 5(2): 257-70.

HUBBERT, Jennifer. 2015. "'We're Not That Kind of Developing Country': Environmental Awareness in Contemporary China." In Cindy Isenhour, Gary Mcdonogh, and Melissa Checker (eds.), Sustainability in the Global City: Myth and Practice. New York: Cambridge University Press. 29-53.

ILES, Alastair. 2004. "Mapping Environmental Justice in Technology Flows: Computer Waste Impacts in Asia." Global Environmental Politics 4(4): 76-107.

LE MEUR, Mikaëla. 2019. "LE MEUR, Mikaëla. 2019. «Plasti-Cités. Enquêtes sur les déchets et les transformations écologiques au Viêt Nam» (Plasti-cities. Investigating waste and ecological transformation in Vietnam). PhD thesis. Brussels: Université libre de Bruxelles." PhD Thesis. Brussels: Université libre de Bruxelles. 
LEPAWSKY, Josh. 2015a. "Are We Living in a Post-Basel World?" Area 47(1): 7-15.

LEPAWSKY, Josh. 2015b. "The Changing Geography of Global Trade in Electronic Discards: Time to Rethink the E-Waste Problem." The Geographical Journal 181(2): 147-59.

LEPAWSKY, Josh, and Chris MCNABB. 2010. "Mapping International Flows of Electronic Waste." The Canadian Geographer 54(2): 177-95.

LIEBMAN, Adam. 2018. "No More of Your Junk." The New Internationalist. October 2018.

LORA-WAINWRIGHT, Anna. 2017. Resigned Activism: Living with Pollution in Rural China. Cambridge, MA:The MIT Press.

MATHEWS, Gordon, Gustavo LINS RIBEIRO, and Carlos ALBA VEGA (eds.). 2012. Globalization from Below: The World's Other Economy. London and New York: Taylor and Francis.

MENG, Xiangfeng, and Tokuhisa YOSHIDA. 2012. "The Impact Analysis of Waste Plastic Trade between China and Japan - From Policy View." In Mitsutaka Matsumoto et al. (eds.), Design for Innovative Value Towards a Sustainable Society. Dordrecht: Springer. 240-45.

MINTER, Adam. 2013. Junkyard Planet: Travels in the Billion-Dollar Trash Trade. London: Bloomsbury.

MOHAl, Paul, David PELLOW, and J. Timmons ROBERTS. 2009. "Environmental Justice." Annual Review of Environment and Resources 34(1): 405-30.

MOORE, Sarah A. 2011. "Global Garbage: Waste, Trash Trading and Local Garbage Politics." In Richard PEET, Paul ROBBINS, and Michael WATTS (eds.), Global Political Ecology. London and New York: Routledge. 133-44.

NI, Hong-Gang, and Eddy Y. ZENG. 2009. "Law Enforcement and Global Collaboration Are the Keys to Containing E-Waste Tsunami in China." Environmental Science \& Technology 43(11): 3991-94.

PELLOW, David N. 2010. "The Global Waste Trade and Environmental Justice Struggles." In Kevin Gallagher (ed.), Handbook on Trade and the Environment. Cheltenham: Edward Elgar Publishing. 225-33.

REBOUX, Rémi. 2017. "Valeur et usages dans une mine urbaine au Kenya. Quelle exploitation des gisements de déchets électroniques à Nairobi ?" (Values and Uses in an Urban Mine in Kenya. What Kind of Exploitation for the Electronic Waste Supply in Nairobi?). Master's Thesis. Marseille: École des Hautes Études en Sciences Sociales.

RENO, Joshua. 2009. "Your Trash Is Someone's Treasure: The Politics of Value at a Michigan Landfill." Journal of Material Culture 14(1): 29-46.

RIVOLI, Pietra. 2005. The Travels of a T-Shirt in the Global Economy: An Economist Examines the Markets, Power, and Politics of World Trade. Hoboken, N.J.: John Wiley \& Sons.

SALA, Alice. Forthcoming. "A Global 'Computer Village': Ethnography of a Long-Distance Trade of Computers \& Allied Products." PhD Thesis. Neuchâtel: University of Neuchâtel.

SCHULZ, Yvan. 2015. "Towards a New Waste Regime? Critical Reflections on China's Shifting Market for High-Tech Discards." China Perspectives 103(3): 43-50.
SCHULZ, Yvan. 2018. "Modern Waste: The Political Ecology of E-Scrap Recycling." PhD Thesis. Neuchâtel: University of Neuchâtel.

SCHULZ, Yvan. 2019. "Scrapping 'Irregulars': China's Recycling Policies, Development Ethos and Peasants Turned Entrepreneurs." Journal Für Entwicklungspolitik 36(2-3): 33-59.

SCHULZ, Yvan, and Anna LORA-WAINWRIGHT. 2019. "In the Name of Circularity: Environmental Improvement and Business Slowdown in a Chinese Recycling Hub." Worldwide Waste 2(1): 9.

SHINKUMA, Takayoshi, and Nguyen Thi Minh HUONG. 2009. "The Flow of E-Waste Material in the Asian Region and a Reconsideration of International Trade Policies on E-Waste." Environmental Impact Assessment Review 29(1): 25-31.

TERAO, Tadayoshi. 2005. "The Rise and Fall of 'Mixed Metal Scrap' Recovery Industry in Taiwan: International Trade of Scraps and Transboundary Relocation." In Michikazu Kojima (ed.), International Trade of Recyclable Resources in Asia. IDE Spot Survey 29. Chiba: IDE, JETRO. 63-84.

TERAZONO, Atsushi et al. 2004. "Material Cycles in Asia: Especially the Recycling Loop Between Japan and China." Journal of Material Cycles and Waste Management 6(2): 82-96.

TONG, Xin, and Jinci WANG. 2012. "The Shadow of the Global Network: E-Waste Flows to China." In Catherine Alexander and Joshua Reno (eds.), Economies of Recycling: The Global Transformations of Materials, Values and Social Relations. London: Zed Books. 98-116.

TONG, Xin, and Dongyan TAO. 2016. "The Rise and Fall of a 'Waste City' in the Construction of an 'Urban Circular Economic System': The Changing Landscape of Waste in Beijing." Resources, Conservation and Recycling 107(February): 10-7.

VELIS, Costas. 2014. "Clobal Recycling Markets - Plastic Waste: A Story for One Player - China." Vienna: International Solid Waste Association. http://www.iswa.org/fileadmin/galleries/Task_Forces/TFGWM_Report GRM_Plastic_China_LR.pdf (accessed on 15 June 2019).

WANG, Feng et al. 2013. "E-Waste in China: A Country Report." Bonn: United Nations University, Institute for Sustainability and Peace. http:// isp.unu.edu/publications/scycle/files/ewaste-in-china.pdf (accessed on 15 June 2019).

XIA, Ying. 2019. "Wealth from Waste? Chinese Investments and Technology Transfer in the Tanzanian Plastic Recycling Industry." Working Paper 27. Washington, DC: Johns Hopkins University.

YOSHIDA, Aya. 2005. "China: The World's Largest Recyclable Waste Importer." In Michikazu Kojima (ed.) International Trade of Recyclable Resources in Asia. Chiba: Institute of Developing Economies, JETRO. 33-52.

ZHANG, Amy. 2019. "Invisible Labouring Bodies: Waste Work as Infrastructure in China." Made in China Journal (April-June). https:// madeinchinajournal.com/2019/07/23/invisible-labouring-bodies-wastework-as-infrastructure-in-china/ (accessed on 22 October 2020).

ZHANG, Jieying 張劼穎. 2015. “垃圾之戰: 廣州的綠色治理, 反焚運動 與科技爭議” (Laji zhi zhan: Guangzhou de lüse zhili, fanshao yundong yu keji zhengyi, Garbage War in Guangzhou: Green Governmentality, AntiIncineration Movements, and Technological Controversies). PhD Thesis. Hong Kong: The Chinese University of Hong Kong. 